\title{
Małgorzata Spychała-Wawrzyniak
}

Uniwersytet im. Adama Mickiewicza w Poznaniu malgorzata.spychala@amu.edu.pl

\section{UCZEŃ ZDOLNY A UDZIAŁ W OLIMPIDZIE JĘZYKOWEJ}

\section{A gifted student and participation in Foreign Language Olympics}

Out of all foreign languages in Polish schools Spanish has achieved the most dynamic increase in popularity within the last few years. For those most fascinated with Spanish and its culture, there have been six editions of the National Spanish Contest in Poland, organised by the M odern Language Association of Poland in cooperation with Adam Mickiewicz University's Institute of Romance Studies. The aim of the article is to present the assumptions and activities of the contest, targeted at the most gifted students, as well as to examine the ways in which the best ones among them prepared themselves, including the amount of time they spent analysing the program guidelines. We will try to address the question whether contest finalists are truly gifted students or merely ones with high language aptitude. Special focus will be placed on finalists' work with their teachers. We are also going to consider possible challenges and problems, which they faced during the preparation process.

Keywords: gifted student, student with language aptitude, Spanish Olympics Słowa kluczowe: uczeń zdolny, uczeń uzdolniony językowo, Olimpiada Języka Hiszpańskiego

\section{W prowadzenie}

W procesie identyfikacji uczniów zdolnych korzysta się z procedur psychologicznych i pedagogicznych polegających między innymi na przeprowadzeniu testów, ankiet, wywiadów, kwestionariuszy i obserwacji danego ucznia (Limont, 2005). W Polsce panuje też przekonanie, że osoby 0 wybitnych zdolnościach biorą 
udział w różnych konkursach i olimpiadach przedmiotowych (Sękowski, 2001; Limont, 2005). Celem artykułu jest analiza sposobów przygotowywania się do ogólnopolskiej Olimpiady Języka Hiszpańskiego (dalej OJH), skierowanej do najbardziej zdolnych i pracowitych uczniów. Przede wszystkim interesuje nas, ile czasu poświęcali uczestnicy finału na opanowanie materiału zawartego w wytycznych programowych olimpiady. Dodatkowo przyjrzymy się ewentualnym trudnościom i problemom, na które napotykali finaliści w trakcie przygotowań. Przedstawimy również zakres działań wspierających uczniów i nauczycieli podejmowanych w ramach olimpiady językowej.

\section{Charakterystyka uczniów wybitnie zdolnych i uzdolnionych językowo}

Biorąc pod uwagę różnorodność koncepcji związanych ze zdolnościami, którymi zajmuje się psychologia, pedagogika, czy edukacja, problem pojawia się już w momencie określenia różnic pomiędzy uczniem zdolnym, uzdolnionym, wybitnym i geniuszem. Limont (2005) zauważa, że termin „zdolności” powinien być łączony z inteligencją, ze zdolnościami ogólnymi, akademickimi lub szkolnymi, gdyż chodzi przede wszystkim o szybkość uczenia się, zapamiętywania i logicznego myślenia. Natomiast „uzdolnienia” to inaczej zdolności kierunkowe, talent, czyli takie cechy, które pozwalają "na uzyskiwanie wysokich osiągnięć w konkretnej dziedzinie aktywności, na przykład w matematyce, muzyce, czy plastyce” (Limont, 2005: 17). „Geniusz” w opinii Alonso y Benito (1996: 42-43) charakteryzuje się dużymi zdolnościami w określonej dziedzinie i jednocześnie tworzy nadzwyczajne dzieła. Z kolei uczeń „wybitny” realizuje różnego typu aktywności odbiegające od przeciętnych zachowań uczniów w tym samym wieku. Jiménez Fernández (2004) podkreśla, że analiza zdolności uczniów wpływa bezpośrednio na ich zachowanie i motywację oraz pomaga nauczycielowi wypracować z nimi odpowiedni model współpracy.

W naszym obszarze zainteresowań znajduje się przede wszystkim koncepcja ucznia uzdolnionego językowo, który przygotowuje się do udziału w olimpiadzie językowej. Jednak biorąc pod uwagę fakt, że olimpiada to konkurs nie tylko znajomości języka, ale też wiedzy na temat kultury, literatury i historii danego obszaru językowego, musimy uwzględnić całokształt zdolności i uzdolnień uczniów biorących udział w tym przedsięwzięciu.

Renzulli $(1978,2011)$ w opracowanym modelu zdolności (giftedness) zakłada, że wybitny rozwój jest możliwy dzięki interakcji pomiędzy trzema podstawowymi cechami ludzkimi, takimi jak: „ponadprzeciętne zdolności” (inteligencja, zdolności akademickie), „wysoki poziom zaangażowania” w zadanie (motywacja) oraz „wysoki poziom kreatywności” (zdolności twórcze) (rysu- 
nek 1). Zdolni i utalentowani młodzi ludzie potrafią rozwijać i stosować wymienione wyżej cechy w każdej potencjalnej wartościowej aktywności ludzkiej. Poza tym wymagają szerokiej gamy możliwości i usług edukacyjnych wykraczających poza regularną ofertę programową (Renzulli, 1978, 2011: 87).

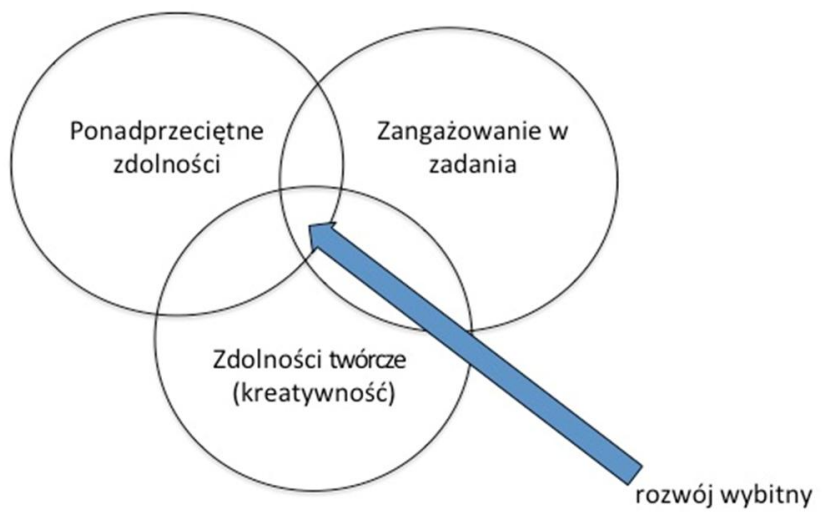

Rysunek 1: Trójpierścieniowy model zdolności (Renzulli, 2011: 86).

M önks (1992) rozwija trójpierścieniowy model Renzullego (1978), dodając trzy inne komponenty będące odzwierciedleniem kontekstu, w którym znajduje się uczeń zdolny: szkołę, rodzinę i rówieśników (rysunek 2). Wszystkie te czynniki wpływają, zdaniem autora, na stabilny rozwój zdolności ucznia. Należy też dodać, że szczególnie rodzina i szkoła powinny ściśle ze sobą współpracować, aby uczeń „obdarzony konkretnymi talentami mógł się rozwijać wszechstronnie i harmonijnie" (Czerwonka, 2010: 53).

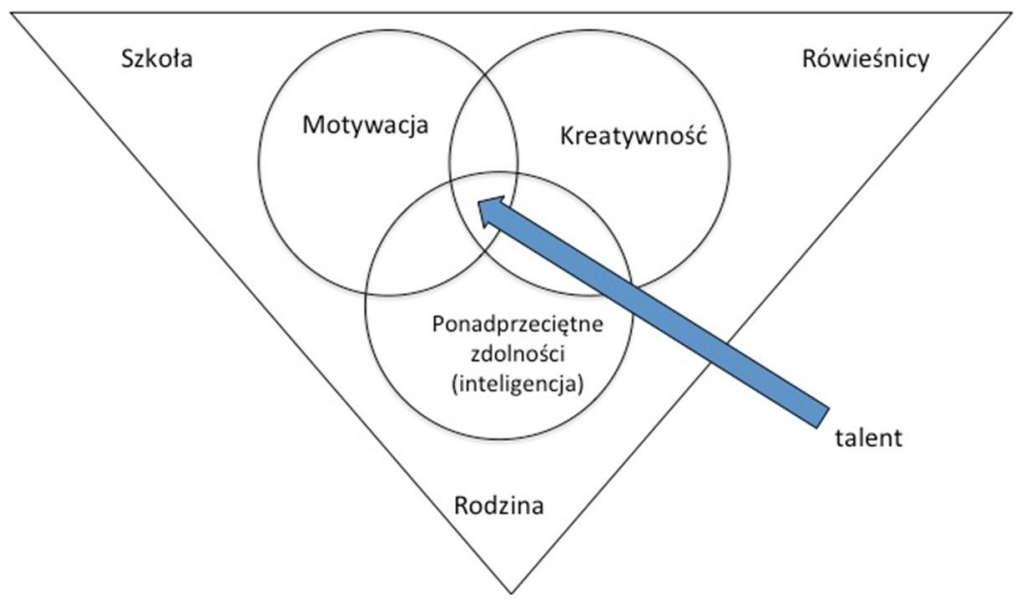

Rysunek 2: Wieloczynnikowy model zdolności M önksa (1992) za Limont (2005: 67). 
Psycholodzy Sękowski i Jurko (2010: 19) wymieniają następujące cechy uczniów zdolnych:

- posiadają duże możliwości zapamiętywania i przetwarzania informacji, efektywnie stosują różne strategie pamięciowe;

- mają dobrą podzielność i koncentrację uwagi;

- charakteryzuje ich postawa dociekliwości, wnikliwość i ciekawość intelektualna oraz dostrzegania istotnych problemów i ich rozwiązywania;

- posiadają zdolności do konceptualizacji;

- potrafią korzystać ze strategii abstrakcyjnego i syntetycznego myślenia;

- dostrzegają zależności przyczynowo-skutkowe;

- mają wysoki poziom inteligencji werbalnej, bogaty zasób słownictwa;

- są zaangażowani i wytrwali w dążeniu do celu;

- są pracowici i silnie koncentrują się na przedmiocie swoich zainteresowań;

- posiadają zdolność trafniejszego i szybszego oceniania rzeczywistości i trudności, z jakimi przychodzi im się zmierzyć;

- są niezależni i preferują indywidualny sposób pracy;

- odznaczają się dużą wrażliwością moralną, jednocześnie mają często problem z zaakceptowaniem autorytetów;

- są empatyczni i dążą do akceptacji ze strony innych (Sękowski i jurko, 2010: 19-20).

Jesteśmy przekonani, że wymienione cechy uczniów zdolnych odnoszą się również do uczniów biorących udział w olimpiadzie językowej, którzy przede wszystkim są uzdolnieni językowo. Warto wyjaśnić, że „uzdolnienia językowe" są często zaliczane do zdolności kierunkowych lub specjalnych (Sobańska-J ędrych, Karpeta-Peć i Torenc, 2013). Biedroń (2008: 29) wyjaśnia, że „W świetle wiedzy naukowej nie można rozpatrywać zdolności językowej pod kątem efektywności procesu uczenia się języka obcego, w oderwaniu od wiedzy z dziedziny genetyki molekularnej, neurologii i psychologii".

Carroll (1965) wyróżnił cztery cechy ucznia dysponującego zdolnościami językowymi: zdolność kodowania fonetycznego, wrażliwość gramatyczną, umiejętność wnioskowania indukcyjnego oraz zdolność uczenia się pamięciowego. Sternberg (2002) dodaje, że oprócz umiejętności zapamiętywania i analitycznego myślenia niezmiernie ważne jest też kreatywne i praktyczne podejście do języka zarówno uczniów, jak i nauczycieli. Autor dodaje, że „ludzie dysponują różnymi typami zdolności i będą uczyć się języka z sukcesem, jeśli droga, którą obrali, dopasowana jest do ich umiejętności" (Sternberg 2002: 15). Uczeń uzdolniony językowo powinien też wykazywać postawę otwartości wobec kultury i języka oraz być zmotywowany (Gardner 1985; Dörnyei 2001).

Majewska (2013: 35) podkreśla, że mówiąc o zdolnościach uczniów biorących udział w olimpiadach językowych, należy pamiętać, że ogromne znaczenie 
mają ich różnice indywidualne, które mogą rozwijać się w sposób dynamiczny w zależności od czynników indywidualnych (cech ucznia) i kontekstu. Powołując się na różnych autorów (m.in. Skehan, 1997; Komorowska, 2002; Dörnyei, 2005), autorka zalicza do różnic indywidualnych między innymi następujące cechy: zdolności językowe, motywację, strategie uczenia się, osobowość, wiek, płeć, kreatywność, inteligencję.

Podsumowując, możemy stwierdzić, że zarówno uczeń zdolny, jak i uzdolniony językowo, to przede wszystkim osoba inteligentna, kreatywna i zaangażowana. Biorąc pod uwagę fakt, że nie jesteśmy psychologami i nie możemy przeprowadzać testów na inteligencję wśród finalistów olimpiady, skupimy się na dwóch pozostałych cechach ucznia zdolnego, a mianowicie zaangażowaniu w zadanie i kreatywności ${ }^{1}$.

\section{Organizacja olimpiad przedmiotowych w Polsce na przykładzie Olimpiady Języka Hiszpańskiego}

Zgodnie z obowiązującym rozporządzeniem M inistra Edukacji i Sportu z 2002 r. (Dz. U. Nr 13, poz. 125 ze zm.) w sprawie organizacji oraz sposobu przeprowadzania konkursów, turniejów i olimpiad, olimpiady przedmiotowe obejmują i poszerzają treści podstawy programowej przedmiotu przewidzianego w ramowym planie nauczania. Olimpiadę organizuje się jako trójstopniowe zawody o zasięgu ogólnopolskim. Uczestnicy muszą wykazać się następującym zakresem wiedzy na poszczególnych etapach konkursu:

1) w zawodach pierwszego stopnia (szkolnych i międzyszkolnych) - wystarczającym do uzyskania oceny bardzo dobrej na zakończenie nauki przedmiotu,

2) w zawodach drugiego stopnia (okręgowych) - niezbędnym do uzyskania oceny celującej na zakończenie nauki przedmiotu,

3) w zawodach trzeciego stopnia (centralnych) - w zakresie wskazanym w programie danej olimpiady.

Ogólnopolska Olimpiada Języka Hiszpańskiego ${ }^{2}$ organizowana była w latach 2010-2016 przez Polskie Towarzystwo Neofilologiczne. Warto zaznaczyć,

\footnotetext{
${ }^{1}$ Szmidt (2013: 25) wyjaśnia, że kreatywność „to swoista zdolność człowieka do generowania nowatorskich (oryginalnych) pomystów rozwiązania różnorodnych problemów praktycznych i poznawczych, z jakimi mamy do czynienia w domu, szkole, zakładzie pracy". W naszym badaniu analizujemy tę cechę, biorąc pod uwagę nowatorskie rozwiązania, z których korzystali uczniowie podczas przygotowywania się do olimpiady.

${ }^{2}$ W latach 2010-2013 OJH organizowana była w ramach Partnerstwa utworzonego w celu realizacji Projektu „Opracowanie i wdrożenie kompleksowego systemu pracy z uczniem zdolnym" wspóffinansowanego zEuropejskiego Funduszu Społecznego w ramach Programu
} 
że organizacja tej olimpiady, począwszy od 2010 roku, była całkowicie nową inicjatywą w Polsce, wynikającą z rosnącej popularności języka hiszpańskiego wśród uczniów szkół ponadgimnazjalnych ${ }^{3}$. Wśród celów olimpiady można wymienić:

- budzenie i rozwijanie wśród uczniów szkół ponadgimnazjalnych zainteresowania językiem hiszpańskim,

- $\quad$ rozszerzenie zakresu i podniesienie poziomu wiedzy uczniów o krajach hiszpańskiego obszaru językowego,

- lepsze przygotowanie uczniów do podejmowania dalszego kształcenia w szkołach wyższych,

- rozwijanie pasji i kształtowania umiejętności samodzielnego zdobywania wiedzy oraz stymulowania aktywności poznawczej młodzieży uzdolnionej,

- rozszerzenie współdziałania nauczycieli akademickich z nauczycielami szkół ponadgimnazjalnych w procesie kształcenia i wychowania młodzieży uzdolnionej,

- $\quad$ stwarzanie młodzieży możliwości szlachetnego współzawodnictwa w rozwijaniu swoich uzdolnień, a nauczycielom - warunków twórczej pracy z młodzieżą, doskonalenie form i metod pracy nauczycieli z młodzieżą uzdolnioną ${ }^{4}$.

Olimpiadę przeprowadzał Komitet Organizacyjny przy wsparciu Komitetu Głównego 5 i ośmiu Komitetów Okręgowych, które znajdowały się w ośmiu ośrodkach akademickich w Krakowie, Warszawie, Poznaniu, Lublinie, Wrocławiu, Bydgoszczy, Łodzi i Katowicach.

W OJH mogli brać udział uczniowie szkół ponadgimnazjalnych: liceów ogólnokształcących, liceów profilowanych, techników, uzupełniających liceów ogólnokształcących i techników uzupełniających dających możliwość uzyskania świadectwa dojrzałości. Za zgodą Przewodniczącego Komitetu Głównego, mogli też zgłosić się uczniowie gimnazjów, zasadniczych szkół zawodowych i szkół zasadniczych realizujących indywidualny program lub tok nauki, rekomendowani przez szkołę. Uczniowie szkół, w których nie nauczano języka hiszpańskiego,

Operacyjnego Kapitał Ludzki. Z kolei w latach 2013-2016 OJH finansowana była ze środków otrzymanych od M inisterstwa Edukacji Narodowej.

${ }^{3}$ W ciągu 5 lat liczba uczniów zainteresowanych obowiązkowym językiem hiszpańskim we wszystkich typach polskich szkół wzrosła prawie trzykrotnie. Zgodnie z danymi Systemu Informacji Oświatowej (M EN) w roku 2010/2011 liczba ta wynosiła 31783 uczniów, a w roku 2015/2016 86020 uczniów, http://www.cie.men.gov.pl/index.php/dane-statystyczne/140.html [DW 2.09.2016].

${ }^{4}$ Regulamin 0JH: www.ojh.edu.pl [14.12.2016].

${ }^{5}$ Komitet Organizacyjny prowadził swoją działalność przy Uniwersytecie im. Adama Mickiewicza w Poznaniu. 
rejestrowani byli przez swoje macierzyste placówki. Liczba uczniów zainteresowanych udziałem w poszczególnych sześciu edycjach olimpiady w latach 20102016 co roku rosła. W VI OJH wzięło udział 1568 uczniów (wykres 1).

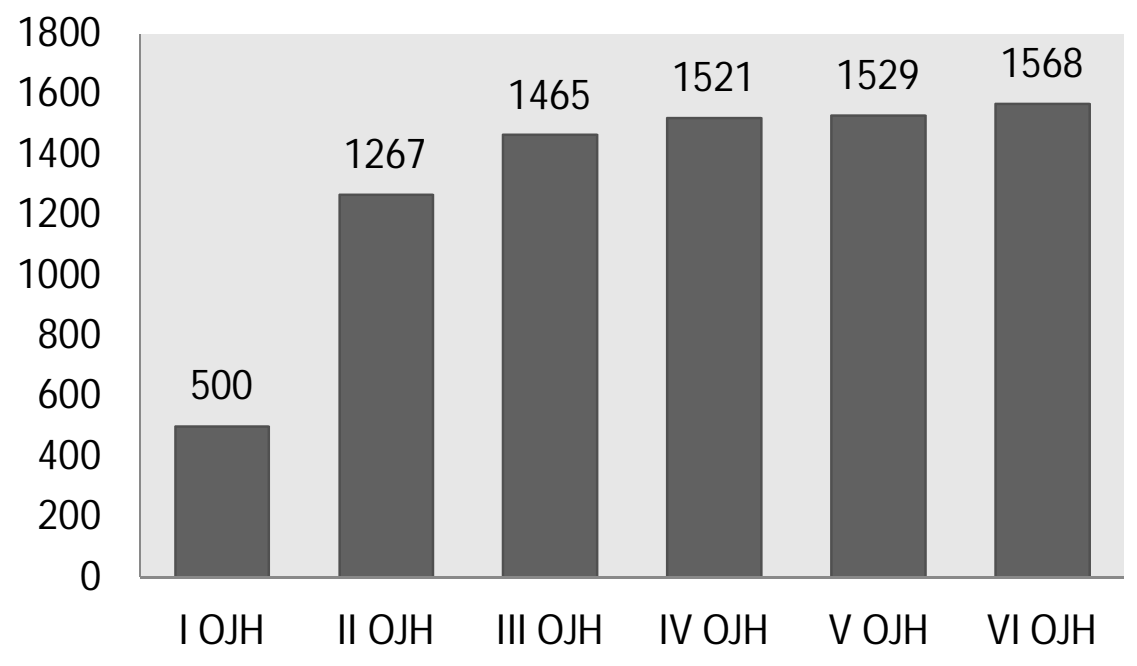

Wykres 1: Liczba uczniów, którzy zarejestrowali się do udziału w 0JH w latach 2010-2016.

Zawody I stopnia polegały na napisaniu przez uczniów testu sprawdzającego znajomość materiału językowego (poziom A2/B1), w formie elektronicznej bądź papierowej. W zawodach II stopnia uczestnicy rozwiązywali test językowy na poziomie B1/B2 oraz test z zakresu wiedzy o krajach hiszpańskiego obszaru językowego. Następnie uczestnicy zakwalifikowani do części ustnej przystępowali do egzaminu ustnego z praktycznej znajomości języka hiszpańskiego oraz literatury hiszpańskiego obszaru językowego. Zawo dy III stopnia polegały na rozwiązaniu testu językowego na poziomie $\mathrm{B} 2 \mathrm{HC}$, napisaniu rozprawki oraz przystąpieniu do egzaminu ustnego z praktycznej znajomości języka hiszpańskiego, literatury hiszpańskiego obszaru językowego i wiedzy o krajach hiszpańskiego obszaru językowego. W przypadku literatury i wiedzy o krajach hiszpańskiego obszaru językowego, uczestników III etapu obowiązywał zakres zagadnień określony w danym roku na etapie okręgowym. Tytuł laureata olimpiady otrzymywało 10 uczestników zawodów III stopnia, którzy uzyskali najlepszy wynik. Status finalisty przyznawany był uczestnikowi, który zdobył minimum $50 \%$ punktów (łącznie z testu i egzaminów ustnych) w zawodach III stopnia.

Należy dodać, że OJH była nie tylko konkursem, ale też przedsięwzięciem, na które składało się wiele wydarzeń towarzyszących związanych z indywidualnym i samodzielnym poszerzaniem wiedzy na temat języka i kultury krajów hiszpańskojęzycznych. Wśród nowatorskich rozwiązań wspierających na bieżąco pracę uczniów 
i ich nauczycieli znalazły się spotkania informacyjno-konsultacyjne (warsztaty) organizowane w całej Polsce, konkurs pt. „En un lugar de.." ${ }^{\prime 6}$, platforma M oodle dostępna na stronie olimpiady, gdzie znajdowały się materiały edukacyjne, takie jak: wywiady, czaty z ekspertami, scenariusze lekcji dla nauczycieli, przykładowe testy. Dodatkowo dla wybranych uczniów (nie będących uczniami klas dwujęzycznych) zorganizowano obóz językowy.

\section{Wyniki badania: udział i przygotowanie finalistów do Olimpiady Języka Hiszpańskiego}

Badanie przeprowadzono w latach 2010-2016 wśród uczestników finału wszystkich edycji Olimpiady Języka Hiszpańskiego. Zebranie danych polegało na analizie uzyskanych odpowiedzi na pytania otwarte i zamknięte w przeprowadzonych ankietach. Analiza miała charakter zarówno ilościowy, jak i jakościowy. Badanie w pierwszej olimpiadzie miało charakter pilotażowy, co pozwoliło na dopracowanie ankiety. W pierwszej części ankiety uczniowie odpowiadali na pytania dotyczące ich ogólnej opinii na temat udziału w olimpiadzie. Druga część kwestionariusza poświęcona była przygotowaniu do olimpiady. W dalszej części finaliści wypowiadali się na temat trudności testów na poszczególnych etapach. Ostatnie pytania dotyczyły spraw organizacyjnych.

W ramach niniejszego artykułu przedstawimy jedynie część badania odnoszącego się przede wszystkim do analizy sposobów przygotowania się uczniów zdolnych i uzdolnionych językowo do udziału w olimpiadzie językowej oraz czasu, jaki poświęcili na zgłębienie wytycznych programowych. Określimy też trudności, z którymi musieli się zmierzyć podczas przygotowań. Interesował nas również zakres współpracy uczestników olimpiady z ich nauczycielami.

W badaniu wzięło udział 209 uczniów będących uczestnikami sześciu edycji olimpiady w latach 2010-2016. Biorąc pod uwagę wszystkie edycje, 54 uczniów uzyskało tytuł laureata, pozostali (155) finalisty. Większość uczestników wszystkich finałów OJH stanowili uczniowie klas dwujęzycznych (73\%) ${ }^{7}$. Poniżej przedstawiamy udział uczniów w poszczególnych edycjach, którzy byli uczniami klas dwujęzycznych z językiem hiszpańskim, i tych, którzy reprezentowali inne oddziały (wykres 2).

${ }^{6}$ Konkurs „En un lugar de..”, czyli w „W jakimś miejscu...", polegał na opracowaniu materiału promocyjnego (broszury) o wybranym miejscu w danym kraju hispanoamerykańskim, np. Ekwadorze, Argentynie, Peru, Urugwaju. Konkurs przeznaczony był dla klas, kół języka hiszpańskiego oraz innych grup uczniów ze szkół uprawnionych do udziału w olimpiadzie. Każda grupa miała wykonać zadanie pod okiem nauczyciela.

${ }^{7}$ W Polsce oddziały dwujęzycznez językiem hiszpańskim funkcjonują w 32 szkołach. 16z nich znajduje się liceach, które finansowane są ze środków Ministerstwa Edukacji Hiszpanii. 


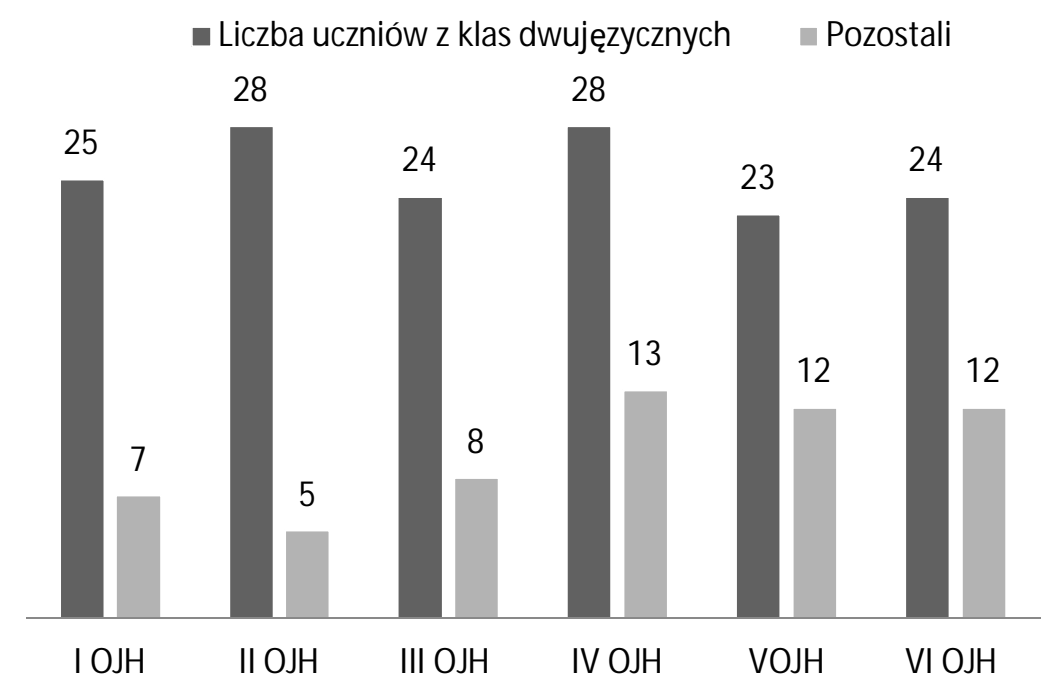

Wykres 2: Uczestnicy sześciu finałów OJH z klas dwujęzycznych i pozostałych.

Większość uczniów (90\%) była zadowolona z udziału w olimpiadzie (wykres 3). U czniowie mieli do wyboru odpowiedzi: zdecydowanie tak, tak, raczej tak, raczej nie, zdecydowanie nie.

\section{Czy jesteś zadowolony z udziału w OJH?}

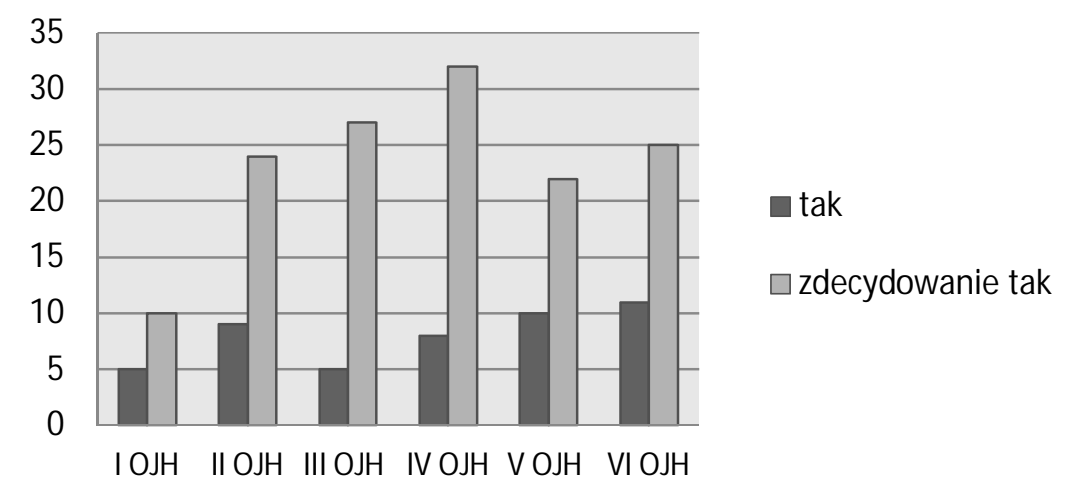

Wykres 3: Odpowiedzi finalistów dotyczące zadowolenia z udziału w OJH.

W pierwszej części ankiety, uczniowie odpowiadali też na pytanie: Jak udział w Olimpiadzie wpłynął na poszerzenie Twojej wiedzy i umiejętności z języka hiszpańskiego i z kultury krajów hiszpańskiego obszaru językowego? Dodatkowo 
mieli dokładnie opisać, na czym ten wpływ polegał. Zanalizy odpowiedzi wynika, że znaczna część finalistów (82,78\%) uznała, że udział w olimpiadzie wpłynął mocno lub bardzo mocno na poszerzenie ich wiedzy. Tylko 6,22\% uczniów uznało, że olimpiada w nieznacznym stopniu wpłynęła na poszerzenie ich wiedzy. 11\% finalistów nie udzieliło odpowiedzi na to pytanie (wykres 4).

\section{Jak wpłynął udział w OJH na poszerzenie Twojej wiedzy?}

\section{qmocno $\square$ bardzo mocno $\square$ średnio}

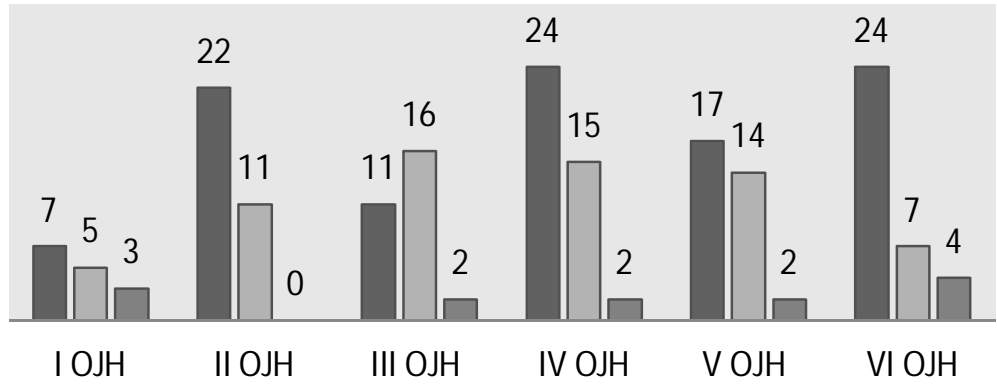

Wykres 4: Samoocena uczniów dotycząca wpływu OJH na ich poszerzenie wiedzy.

Należy zaznaczyć, że finaliści w przeważającej części przyznali, że poszerzenie wiedzy polegało w głównej mierze na poszukiwaniu informacji z zakresu historii i kultury krajów hiszpańskojęzycznych, poznaniu nowego słownictwa, a także pogłębieniu wiedzy z zagadnień gramatycznych.

Jeśli chodzi o czas, jaki uczniowie poświęcili poza szkołą na przygotowanie się do olimpiady, to z analizy ankiet wynika (wykres 5), że najmniej czasu poświęcili na przygotowanie się do pierwszej edycji OJ H, co można wyjaśnić tym, że wówczas dopiero rozpoczynano organizację tego przedsięwzięcia w Polsce. W tym czasie również dość późno ogłoszono wytyczne programowe konkursu. Ta sytuacja z pewnością wpłynęła na mniejszą liczbę godzin poświęconych na przygotowanie się w porównaniu z kolejnymi edycjami olimpiady. Warto odnotować, że średnio poza lekcjami uczniowie przeznaczali około 90 godzin na przygotowanie się do konkursu w danym roku szkolnym. Większość uczniów przyznała, że uczyła się kilka godzin dziennie przez kilka tygodni przed każdym etapem. 
$\square$ średnia liczba godzin

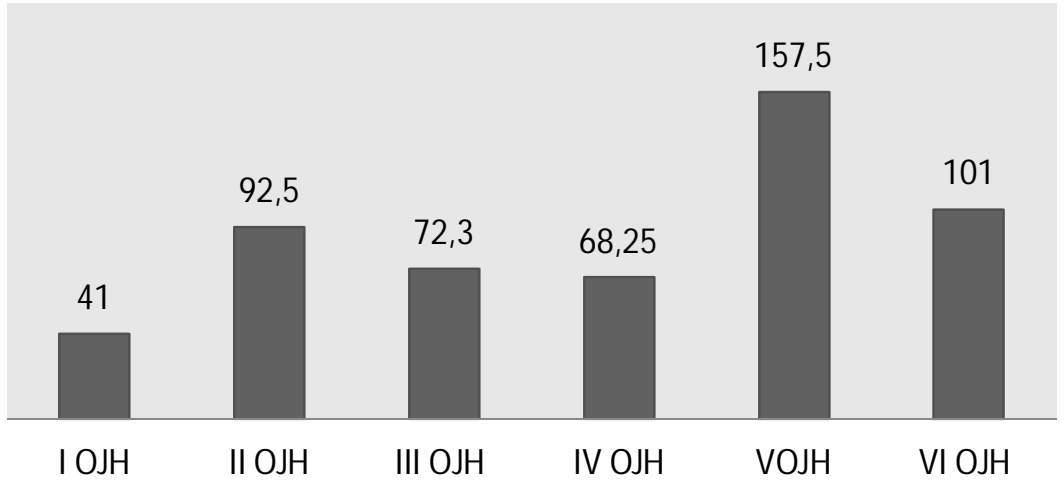

Wykres 5: Liczba godzin (poza lekcjami szkolnymi) poświęcona na przygotowanie się do danej edycji OJH.

Dane przedstawione na kolejnym wykresie (wykres 6) pokazują, że uczniowie przygotowując się do olimpiady, najwięcej informacji czerpali z książek i z Internetu. Zaznaczali, że korzystając z Internetu, uczyli się też z materiałów dostępnych na platformie Moodle olimpiady, szczególnie podczas pierwszych trzech edycji OJ $\mathrm{H}^{8}$. Większość z nich samodzielnie opracowywała tematy z programu olimpiady, robiąc notatki. W mniejszym zakresie skupiali się na ćwiczeniach z gramatyki i słownictwa. Niewiele czasu poświęcali na oglądanie filmów i programów hiszpańskojęzycznych. W małym stopniu korzystali też z dodatkowych prywatnych lekcji. Rzadko rozmawiali z innymi uczestnikami, pisali rozprawki czy ćwiczyli sprawność słuchania. Na uwagę zasługuje strategia uczenia się polegająca na "rozmowie z samym sobą", z której korzystało kilku uczniów. Zastanawia natomiast zakres współpracy z nauczycielem, gdyż niewielu uczniów przyznało, że korzystało z konsultacji czy materiałów poleconych przez nauczyciela. Odwołując się do wcześniej zaprezentowanego wieloczynnikowego modelu zdolności M önksa (1992 za Limont, 2005: 67), możemy stwierdzić, że w tym konkretnym przypadku uczniowie w niewielkim zakresie korzystali ze wsparcia ze strony szkoły, rodziny czy rówieśników. Zdecydowanie dużo większą wagę podczas przygotowań przywiązywali do samodzielnej pracy.

${ }^{8}$ Należy przypomnieć, że w pierwszych trzech latach olimpiada finansowana była ze środków Unii Europejskiej, co pozwoliło na opracowanie wielu materiałów merytorycznych na platformie M oodle OJH przez wybitnych specjalistów hiszpańskojęzycznych. 


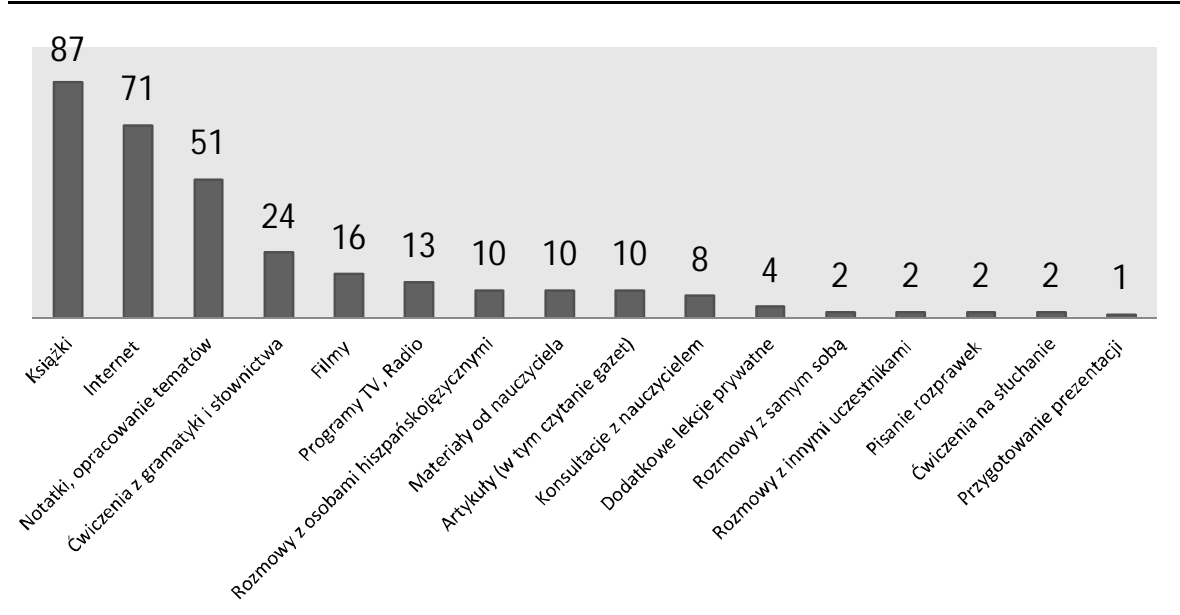

Wykres 6: Sposoby przygotowania się uczniów do OJH w latach 2010-2016.

Jedno z pytań ankiety dotyczyło trudności, z jakimi musieli się zmierzyć finaliści podczas przygotowywania się do olimpiady. Zebrane odpowiedzi (wykres 7) pokazują, że najbardziej problematyczny okazał się bardzo szeroki zakres materiału do opanowania z kultury i historii krajów hiszpańskojęzycznych. Na kolejnym miejscu znalazła się kultura krajów Ameryki Łacińskiej. Uczniowie wyjaśniali, że rzadko ta tematyka poruszana jest na lekcjach, gdyż częściej mówi się o kulturze Hiszpanii. Skarżyli się też, że mieli mały dostęp do informacji i materiałów na temat kultury krajów takich jak: Kuba, Boliwia, Wenezuela, Panama, etc.

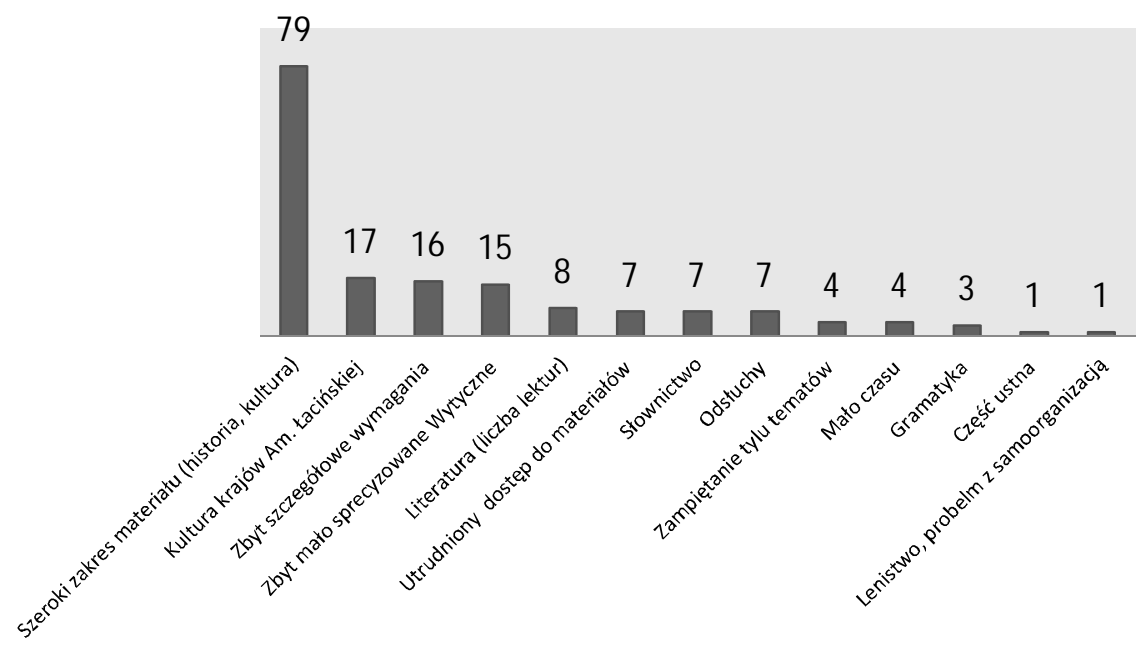

Wykres 7: Trudności uczniów podczas przygotowywania się do OJH w latach 2010-2016. 
Warto na koniec zaprezentować problemy, jakie pojawiły się podczas części pisemnej w trakcie trzeciego etapu zawodów. Pytanie brzmiało: Co sprawiło Ci szczególnq trudność w testach podczas etapu centralnego?. Uczniowie zaznaczyli, że mieli duże trudności ze sprawnością czytania, a także słuchania ze zrozumieniem. Ankietowani wskazywali, że ciężko było im zrozumieć osoby, które rozmawiały podczas nagrania przez telefon. Niektórzy dodawali, że na lekcjach rzadko ćwiczone były te sprawności. Na trzecim miejscu pojawiło się trudne słownictwo oraz idiomy.

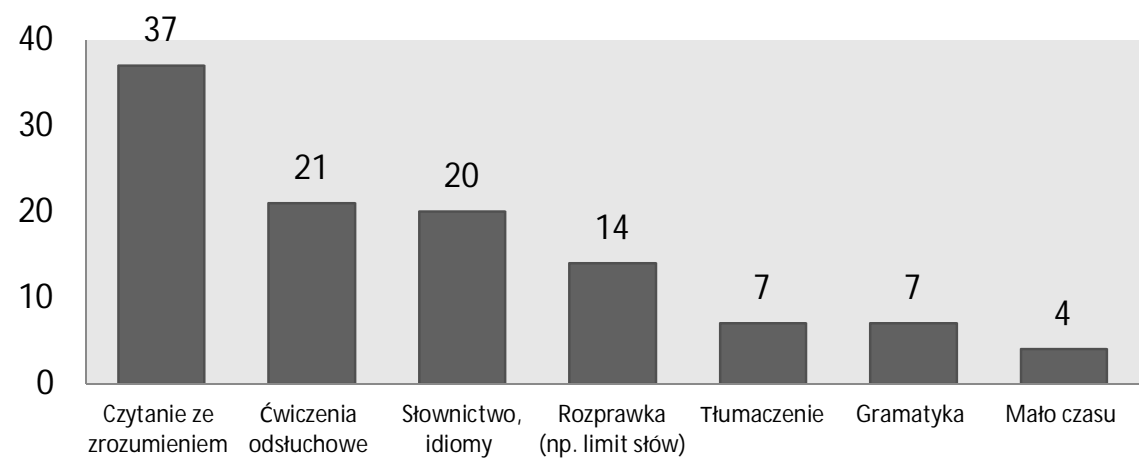

Wykres 8: Trudności uczniów podczas części pisemnej (finał) OJH w latach 2010-2016.

\section{Podsumowanie i wnioski}

Przedstawione powyżej wyniki badania pokazują, że uczeń, który przygotowuje się do olimpiady językowej, to nie tylko uczeń uzdolniony językowo, ale przede wszystkim to uczeń zdolny, który jest dociekliwy, ciekawy, zaangażowany, wytrwały i pracowity. Zdecydowanie preferuje autonomiczny tryb pracy, stosuje różne strategie uczenia się i zapamiętywania oraz posiada zdolność krytycznej analizy rzeczywistości oraz trudności, z jakimi musi się zmierzyć (por: Sękowski i Jurko, 2010: 19-20).

Największy procent uczestników finałów OJH stanowili uczniowie klas dwujęzycznych (ponad 70\%). Zdecydowana większość była zadowolona z udziału w olimpiadzie, dodając, że udział w tym przedsięwzięciu wpłynął mocno lub bardzo mocno na poszerzenie ich wiedzy.

Uczniowie przygotowywali się średnio kilkadziesiąt godzin, szczególnie przed II i III etapem. Naukę zaczynali najczęściej po ogłoszeniu wyników (od 2 do 4 tygodni). Całkowity czas pracy wynosił od 40 do ok. 150 godzin. Przygotowując się do konkursu, w największym stopniu korzystali z książek oraz z wiadomości zaczerpniętych z Internetu, w tym korzystali z materiałów, które udostępniał na platformie M oodle Komitet Organizacyjny OJH. Najczęściej stosowaną strategią 
uczenia się było robienie notatek i opracowanie poszczególnych tematów zawartych w programie olimpiady, co pozwoliło im na zapamiętanie tak obszernego materiału.

Najwięcej problemów sprawiło uczniom zgłębienie zagadnień historycznych i kulturowych krajów hiszpańskojęzycznych (obszerny zakres materiału). Wiele trudności w przygotowaniu do części pisemnej (finał) przysporzyły uczniom zadania dotyczące rozumienia tekstu słuchanego oraz pisanego (w tym skomplikowane słownictwo), co potwierdzają też wyniki dotyczące sposobów przygotowania się do olimpiady. Uczniowie przyznali, że przed olimpiadą w niewielkim stopniu skupiali się na ćwiczeniu sprawności rozumienia tekstu pisanego i słuchania ze zrozumieniem.

Podsumowując, należy stwierdzić, że olimpiada językowa stanowi ogromne wyzwanie dla najbardziej aktywnych i zdolnych uczniów. Nie wystarczy dysponować bardzo dobrą znajomością języka. Każdy uczestnik musi wykazać się też wiedzą na temat kultury, historii oraz literatury. Obszerny zakres materiału do opanowania sprawia, że uczniowie muszą samodzielnie określić, w jaki sposób będą się przygotowywać do olimpiady, ile czasu dziennie poświecą temu wyzwaniu oraz z jakiego typu strategii uczenia będą korzystać podczas przygotowań. Wymienione cechy świadczą niewątpliwie o dużym zaangażowaniu uczniów w zadanie. Natomiast nie jesteśmy w stanie stwierdzić, czy finaliści to osoby kreatywne, czyli dysponujące zdolnościami do „w miarę częstego generowania nowych i wartościowych wytworów" (Szmidt, 2013: 24), choć niewątpliwie potrafią rozwiązywać pojawiające się przed nimi problemy, np. dotyczące poszukiwania materiałów niezbędnych do opanowania określonej wiedzy.

Jesteśmy przekonani, że olimpijczycy, którzy dostają się do części finałowej, to z pewnością uczniowie wybitni, zdolni, ambitni, traktujący udział w olimpiadzie jako przede wszystkim możliwość poszerzenia wiedzy i docelowo uzyskania punktów, które pozwolą im między innymi dostać się na wybrane przez nich wyższe uczelnie.

\section{BIBLIOGRAFIA}

Alonso, J. A., Benito, Y. 1996. Superdotados: adaptación escolar y social en Secundaria. Madrid: Narcea, SA. De Ediciones.

Biedroń, A. 2008. „Teoria świadomego postrzegania (noticing). Intencja i świadomość w akwizycji drugiego języka". (w) Autonomia w nauce języka obcego - co osiqgnęliśmy i dokqd zmierzamy. (red. M. Pawlak). Kalisz: Wydział Pedagogiczno-Artystyczny UAM w Kaliszu, str. 45-52.

Carroll, J. B. 1965. „The prediction of success in intensive foreign language training”. (w) Training, research, and education. (red. R. Glaser). New York: Wiley, str. 87-136. 
Czerwonka, D. 2010. „Środowisko rodzinne dzieci wybitnie zdolnych”. (w) Osobowościowe i środowiskowe uwarunkowania rozwoju ucznia zdolnego. (red. W. Limont, J. Cieślikowska, J. Dreszer). Toruń: Wydawnictwo Naukowe Uniwersytetu Mikołaja Kopernika, str. 53-61.

Dörnyei, Z 2001. Teaching and Researching M otivation. Harlow: Pearson Education Limited. Dörnyei, Z. 2005. The Psychology of the Language Learner. New York: Routledge.

Gardner, R. C. 1985. Social Psychology and Second Language Learning. The Role of Attitudes and Motivation. Baltimore: Edward Arnold.

Jiménez Fernández, C. 2004. „Alumnos superdotados: Caracterización e identificación". (w) Diagnóstico y atención a los alumnos con necesidades educativas específicas: alumnos intelectualmente superdotados. M adrid: Secretaria General de Educación del M inisterio de Educación y Ciencia, str. 11-43.

Komorowska, H. 2002. M etodyka nauczania języków obcych. Warszawa: Fraszka Edukacyjna. M ajewska, R. 2013. „El alumno (super)dotado según las teorías de las diferencias individuales". (w) El alumno de ELE: un alumno extraordinario. Marco teórico y propuestas prácticas para trabajar en la clase de Español Lengua Extranjera (ELE). (red. L. Sagermann Bustinza, J. Hadaś). Poznań. Komitet Główny Olimpiady Języka Hiszpańskiego, str. 33-49.

Mönks, F. J. 1992. „Development of gifted children: The issue of identification and programming". (w) Talent for the Future: Social and Personality Development of Gifted Children: Proceedings of the Ninth World Conference on Gifted and Talented Children. (red. F. J. M önks, W. Peters). Assen, The Netherlands: Van Gorcum, str. 191-202.

Limont, W. 2005. Uczeń zdolny. Jak go rozpoznać i jak z nim pracować. Gdańsk: GWP. Renzulli, J. S. 1978, 2011. „What Makes Giftedness? Reexamining a Definition". Phi Delta Kappan 60, 3, str. 180-184. https:/gseuphsdlibrary.files.wordpress.com/ 2013/03/what-makes-giftedness.pdf DW 13.08.16.

Rozporządzenie M inistra Edukacji Narodowej i Sportu z dnia 29 stycznia 2002 r. w sprawie organizacji oraz sposobu przeprowadzania konkursów, turniejów i olimpiad (Dz. U. nr 13, poz. 125 ze zm.).

Sękowski, A. 2001. Osiągnięcia uczniów zdolnych. Lublin: Towarzystwo Naukowe Katolickiego Uniwersytetu Lubelskiego.

Sękowski, A., Jurko, M. 2010. „Wybitne zdolności jako wymiar psychologiczny i pedagogiczny". (w) Osobowościowe i środowiskowe uwarunkowania rozwoju ucznia zdolnego. (red. W. Limont, J. Dreszer, J. Cieślikowska). Toruń: Wydawnictwo Naukowe Uniwersytetu M ikołaja Kopernika, str. 11-31.

Skehan, P. 1997. Individual Differences in Second-Language Learning. London: Arnold. Sobańska Jędrych, J., Karpeta-Peć, B., Torenc, M. 2013. Rozwijanie zdolności językowych na lekcji języka obcego. Warszawa: Ośrodek Rozwoju Edukacji.

Sternberg, R. J. 2002. "The theory of successful intelligence and its implications for language aptitude testing". (w) Individual Differences and Instructed Language Learning. (red. P. Robinson). Amsterdam: John Benjamins B.V., str. 13-44.

Szmidt, K. T. 2013. Trening kreatywności. Podręcznik dla pedagogów, psychologów i trenerów grupowych. Gliwice: Helion. 